\title{
Afrasian Connectivities-Entangled Cultures, Literatures and Politics Between Africa and India
}

\section{Towards a Transregional Polylogue}

\author{
Nilufer Bharucha \\ CoHaB Indian Diaspora Centre, University of Mumbai, Mumbai, India \\ nbharucha@cohab.mu.ac.in \\ John Njenga Karugia | ORCID: 0000-0001-7932-3950 \\ Institute of Asian and African Studies, Humboldt Universität zu Berlin, \\ Berlin, Germany \\ karugiaj@hu-berlin.de

\begin{abstract}
Mala Pandurang | ORCID: 0000-0002-4435-464X
Dr. BMn College (Autonomous), SNDT Women's University, Mumbai, India mpandu@yahoo.com
\end{abstract}

\author{
Frank Schulze-Engler \\ Goethe-Universität Frankfurt, Frankfurt, Germany \\ schulze-engler@nelk.uni-frankfurt.de
}

'Afrasia' may be a relatively recent term, introduced by authors such as Seifudein Adem and Ali Mazrui, ${ }^{1}$ Gaurav Desai, ${ }^{2}$ Michael N. Pearson, ${ }^{3}$ and further explored by the "Africa's Asian Options" (AFRASO) Research Project at Goethe University Frankfurt, ${ }^{4}$ but the historical, political, economic, social and cultural

1 Ali A. Mazrui and Seifudein Adem, Afrasia: A Tale of Two Continents (Lanham, MA: UP of America, 2013).

2 Gaurav Desai, Commerce with the Universe: Africa, India and the Afrasian Imagination (New York: Columbia UP, 2013).

3 Michael N. Pearson, Port Cities and Intruders: The Swahili Coast, India, and Portugal in the Early Modern Era (Baltimore, MD: Johns Hopkins UP, 1998); see particularly Chapter 2 ("The Swahili Coast in the Afrasian Sea").

4 See, for example, Ruth Achenbach, Jan Beek, John Njenga Karugia, Rirhandu Mageza-Barthel and Frank Schulze-Engler (eds.), Afrasian Transformations: Transregional Perspectives on Development Cooperation, Social Mobility and Cultural Change (Leiden: Brill, 2020). For fur- 
connectivities it denotes have shaped transregional relations between Africa and Asia for many centuries. Looking at these relations through an Afrasian lens does not imply setting them into a "territorial container" or a "geopolitical mega-area;" instead Afrasia is meant to indicate "an emerging space of connective interaction and a new heuristics for coming to terms with entangled areas and intertwined histories in a decentred world that can no longer be grasped through the Eurocentric categories that dominated the theory and practice of area studies for so long."

In this spirit, the focus of this special issue of Matatu on connectivities and entanglements between East and Southern Africa and the Indian subcontinent aims to be inclusive rather than exclusive, highlighting one particularly important facet of Afrasian connectivities without suggesting that they are the only ones that matter in African-Asian relations or that they are not in turn interconnected to other transregional spaces encompassing further parts of Asia, the Arab world, Europe or the Americas. The contributions to this special issue share an interest both in the long duration and the diversity and heterogeneity of Afrasian connectivities that have traversed national, religious, and ethnic boundaries, that have generated transregional entanglements that at times blur the boundaries between allegedly national histories, and that have decisively shaped societies, cultures, and literatures in Africa and Asia.

The first essay by Fahad Bishara on "History at Sea: Route and World on an Indian Ocean Dhow" examines an expansive temporal and spatial canvass linking Arabia, Africa and South Asia for many centuries and portrays the Indian Ocean world as an interconnected maritime space of commerce, politics and the imagination. Focusing on early 2oth century logbooks and nautical manuals of dhow captains (nakhodas) from Kuwait, Bishara highlights "the human and imaginative processes that produce the Indian Ocean as an historical arena" (12) and shows how these texts project "a sense of the Indian Ocean as a web of possible routes, rather than an abstract space" (19). The narrative emerging from these texts, the essay argues, "disassembles the nation-state or other container-based model of writing world history" (30) and establishes maritime roots as an alternative mode of articulating the global histories of European Arab and African empires with local constellations: "If littoral societies looked out across the water to one another, then the maritime route lets us

ther information on the AFRASO project (2012-2019) see www.afraso.org (last acc. 15th October, 2021).

5 Achenbach et al., Afrasian Transformations, 3 . 
see the histories that connected them to one another and that entangled their lives with the long history of empire" (31).

Villoo Nowrojee's piece on "Ceramics in Indian Ocean Trade" provides a fascinating case study of the complex make-up of transregional commercial relations extending from Africa to China and East Asia, with India and Malaysia as important commercial hubs between Chinese porcelain producers and East African consumers along the Swahili coast, for whom Chinese plates became important markers of social prestige and standard features of 'traditional' interior decoration. For many centuries, the porcelain commerce was in the hands of African, Arab and Asian traders, but after 1800 European manufacturers began to dominate the market with mass-produced Chinaware, copying East Asian designs and adapting their produce to the tastes of Muslim cultures along the Swahili Coast. The essay provides impressive evidence for the manner in which Afrasian connectivities have shaped local East African material culture for many centuries, and at the same time shows how these connectivities became inextricably entangled with transregional relations to Europe in the age of imperialism.

Neelima Jeychandran's essay on "African Spectral Pasts and Their Presences on the Malabar Coast" delves into the role of African spirits-locally referred to as Kappiri-in the coastal regions of Kochi in Kerala and thus on another Afrasian connection (the trafficking of African slaves to India during Portuguese and Dutch colonialism) that continues to shape everyday lifeworlds, this time in India. The shrines built to acknowledge Kappiri (as well as their numerous appearances in local folklore, for example as guardians of hidden treasures) testify to "the hidden histories of the colonial slave trade of Africans" (66) and testify to the significance of "spectral histories" as an important facet of "Afro-Asian connections beyond the space of port cities and coastal belts" that "yoke Afro-Asian affinities through the material, mnemonic, ecological, and ritualistic domains" (67).

Uma Mesthrie's essay "South Africa to India: Narratives of a Century of Repatriation (1871-1975)" provides further impressive evidence for the fact that Afrasian connectivities never constituted a one-way dynamics. The essay provides a counterpoint to the priorisation of the movement of Indians to South Africa and engages in intensive archival work, focusing on repatriation from Cape Town, to make the complicated life stories of repatriates visible. Once more, on closer scrutiny, "Indians" in South Africa turn out to be manifestly diverse, both with regard to geographical and ethnic origins and to linguistic, religious and cultural belongings. While the longing for the "motherland" many diasporic repatriates had never seen was often cruelly disappointed, and the dominant story recorded in the archives is one of loss, regret and 
suffering, the essay suggests that "we need to complicate the story of repatriation and recognise the diversity of stories of men and women and children, not all of which were bleak and miserable" (98).

Pheroze Nowrojee's essay on "The Indian Freedom Struggle and the Kenyan Diaspora-Values across the Ocean: 1916-1963" points to the decisive role that the political struggles of Indians in Kenya played for the development of the freedom struggle in India. Embedding twentieth-century anticolonial politics in a two thousand year-old history of interaction across the Indian Ocean, Nowrojee argues that it was the Kenyan Indians' struggle for equality and dignity in Kenya with a White Supremacist settler regime that in India produced a decisive shift from the goal of Dominion Status to the aim of complete Independence as a Republic and played a pivotal role in the transformation of the Congress Party "from a middle-class party controlled by professionals into a mass movement for an irreversible national demand" (109). In turn, "the Indian freedom struggle and a free India became a major influence upon Kenya's own mass freedom movement" (109) and had a decisive political impact across ethnic and racial boundaries that have become 'naturalized' in the course of the 2oth century. Summing up the protracted entanglements of Kenyan and Indian politics, Nowrojee warns that "the events of 1919-1923 are not mere connections", but that in this unique period, one can find "Kenyan history in India, and Indian history in Kenya" (109).

Kanya Padayachee's essay on "An Afrasian Entanglement: Reinforcing Democracy in South Africa through Gandhi and His Legacy" scrutinizes Gandhi's time in South Africa that "made a remarkable impact on him and the country, transforming his political and social positions and influencing its struggle for freedom" (111). The essay traces the development of Gandhi's political philosophy and leadership from an earlier phase focusing entirely on the political resistance of Indians in South Africa towards a later phase acknowledging the necessity of joint struggles and notes "a progressive shift from his exclusionary politics in defence of the Indians in South Africa to the inclusivity of 'political cooperation' with all 'non-White' oppressed people" (124). Today, the Phoenix Settlement established by Gandhi as an ashram in South Africa in 1904 and the Gandhi Development Trust (GDT) launched in 2002 by Gandhi's followers are major institutions that carry Gandhi's legacy forward into the democratic South Africa and support social programmes dedicated to "the promotion of Gandhian and Ubuntu values of social responsibility, peace, nonviolence and citizenship" (130).

Frank Schulze-Engler's essay on "Afrasia at War: Transregional Imaginaries in Biyi Bandele's Burma Boy" widens the scope of this issue to a nonlittoral perspective on Afrasian connectivities. The tens of thousands of West 
African soldiers who volunteered to fight against the Japanese in South Asia in World War II did not follow ancient trade routes, but became part of a global machinery of war in which they have often been assigned the role of victims of "a white man's war." The essay shows that Bandele's novel Burma Boy ${ }^{6}$ follows a different track in presenting the story of a young volunteer who eventually comes to fight in Ordre Wingate's notorious "Chindit" Unit behind the lines in Japanese-occupied Burma: Ali Banana does not come across as a cog in somebody else's war, but his eccentric story "not only promote a more thorough understanding of individual and collective war experiences, but also make[s] a valuable contribution to decentring global war narratives and realigning war memories" (145).

Nilufer Bharucha's essay on "Memory, Re-memory and Post-memory: Pheroze Nowrojee's Journey into Kenyan Landscapes" reads Nowrojee's family memoir, A Kenyan Journey (2014), ${ }^{7}$ as a re-memory and post-memory text in which diasporic memories of India as well as questions of national affiliation in Kenya are negotiated. Once more, both "India" and "Kenya" emerge as heterogenous, complex and entangled entities: Nowrojee's grandfather, who came to East Africa in the late nineteenth century, was a Zoroastrian Parsi and thus - like the author Pheroze Nowrojee himself-belonged to a "double diaspora, where for the first generations, India too is a memory, and for the second and third generations, India-like Iran-becomes a matter of re-memory/ post-memory" (149). A Kenyan Journey thus chronicle numerous journeysincluding that of Nowrojee's grandfather, who became a well-respected train driver, into Kenyan citizenship - and testifies to ethnic tensions in colonial Kenya, but also to the fact "that there was a shared sympathy of a subject people for another subject people" (158).

Memory and re-memory also play a major role in Preeti Shirodkar's essay on "Spaces and Faces: Exploring Identity and Identification in M.G. Vassanji's Writing." The essay examines Vassanji's affiliations - both those he was born into and those he acquired in life - and his identity "spread across India, Africa, America and Canada" and examines their constitutive role in his writings: "his books are thus set in all these homes whose reality he explores with equal candour and flourish, also occupying [...] an in-between space, echoing the eternal différance of a diasporic" (163). In his fictional and non-fictional work alike, Vassanji thus emerges as a writer who inhabits multiple pasts, "shaped by the spaces to which he belongs and which have left an indelible mark on him and

6 Biyi Bandele, Burma Boy (London: Jonathan Cape, 2007).

7 Pheroze Nowrojee, A Kenyan Journey (Nairobi: Transafrica Press, 2014). 
which he (as a person and part of a community) has also shaped in irreversible ways" (173).

Justus Makokha's "Afrasian Aesthetics in M.G. Vassanji's The Magic of Saida: A Reflection" continues the engagement with "the leading Afrasian author in recent times" (176) by exploring the tensions and ambiguities in the identity of Kamal Punja, the protagonist of one of Vassanji's later novels who grows up as the son of an Indian trader and an African mother in the East African coastal town of Kilwa, is later sent to his Indian relatives in Dar-es-Salaam to become "Indian", emigrates to Canada, and finally returns to Kilwa to search for Said, the lost love of his youth. The essay highlights "the fragmented narrative(s), and the jumps between past and present, Africa, Asia and North America in The Magic of Saida" as a major feature of the novel's Afrasian aesthetics and shows how the non-linear sequence and the entanglements of personal and public history in the text act as a counterpoint to Kamal's attempts to identify himself unequivocally as "African" or "Indian". Although Kamal ultimately fails to achieve a complete sense of selfhood, "he succeeds in understanding that selfhood is not as simple as he thought—and the people around him thought during his youth" (186).

The essay by Delphine Munos on "Afrasian Entanglements and Generic Ambiguities in Sultan Somjee's Bead Bai" discusses literary strategies of "genrebending" in a "factional" text setting out the little-known story of "Asian African women who sorted out, arranged and looked after ethnic beads during colonial times in East Africa" and argues that "by toying with the boundary between fiction and ethnography, Somjee opens new gendered avenues for reinserting the category of the imaginary at the heart of Afrasian entanglements" (188). Once more, the idea of "Asians" or "Indians" in Kenya (often stereotypically reduced to male traders) is complicated in Bead Bai ${ }^{8}$ by the Satpanth Ismaili faith and caste identity embraced by the female protagonist, "itself a minority religion in India, as it represents a unique syncretism between Hinduism and Islam and merges the teachings of Hindu gurus and Moslem pirs" (192). Charting a path between critical positions warning against a romanticization of African-Indian relations in Africa and those pointing out that the idea of Asian "insularity" in Africa may itself be biased, Munos argues that Somjee's text adds another layer of complexity by "capturing the tensions within the Khoja community of East Africa, notably by bringing gender into the equation" (205).

8 Sultan Somjee, Bead Bai (Charleston: CreateSpace Independent Publishing Platform, 2012). 
Finally, John Njenga Karugia's interview with Neera Kapur-Dromson, the author of From Jhelum to Tana, ${ }^{9}$ on "The Indian Ocean as a Memory Space" explores the complex histories and transformations of "Asian Africans" in Kenya. Kapur-Dromson, who was born in Nairobi, whose ancestral roots are in Pakistan (India before partition), and who today lives in Kenya and France, highlights the diversity of "Kenyan Asians" who have never formed "a monolithic group but a mix of complex groups depending on their geographic origins, language variations, food and dietary patterns, religious and ritualistic affiliations" (226). This is why she remains skeptical of the recent decision to acknowledge "Kenyan Asians" as "44th tribe of Kenya"; instead of following a tribalist logic (that ultimately was an invention of colonialism) she believes the hybrid cultures that have emerged with intermarriage, migration, integration and education need to be acknowledged and holds it "imperative to identify ourselves as concerned and responsible citizens, cultivating ethical relationships: human rights, concern for migrants, refugees and ecology" (222).

While the coverage of Afrasian connectivities and entanglements in this special issue is necessarily exemplary rather than encyclopedic, the broad interdisciplinary scope of the contributions assembled here is meant to further exchange between different academic fields and to stimulate further research. The common focus on the long histories of these connectivities and entanglements that complicate homogenizing visions of cultures, societies and nations in Africa and Asia and necessitate more discerning inquiries into collectivities whose homogenous identities have often been taken for granted arguably lends these contributions a sense of coherence as well as urgency. While not shirking away from exploring tensions and conflicts between and within various communities in Africa and Asia, the essays assembled here also explore the possibilities of cooperation, exchange and (often contested) solidarities. At a time when populist nationalisms and exclusivist demands for putting one's own country first seem to be on the rise in numerous parts of the globe, highlighting the possibility and exigency of transregional polylogues seems imperative-in academia and beyond.

9 Neera Kapur-Dromson, From Jhelum to Tana (New Delhi: Penguin, 2007). 


\section{Works Cited}

Achenbach, Ruth, Jan Beek, John Njenga Karugia, Rirhandu Mageza-Barthel, and Frank Schulze-Engler (eds.), Afrasian Transformations: Transregional Perspectives on Development Cooperation, Social Mobility and Cultural Change (Leiden: Brill, 2020). Bandele, Biyi. Burma Boy (London: Jonathan Cape, 2007).

Desai, Gaurav. Commerce with the Universe: Africa, India and the Afrasian Imagination (New York: Columbia UP, 2013).

Kapur-Dromson, Neera. From Jhelum to Tana (New Delhi: Penguin, 2007).

Mazrui, Ali A. and Seifudein Adem. Afrasia:A Tale of Two Continents (Lanham, MA: UP of America, 2013).

Nowrojee, Pheroze. A Kenyan Journey (Nairobi: Transafrica Press, 2014).

Pearson, Michael N. Port Cities and Intruders: The Swahili Coast, India, and Portugal in the Early Modern Era (Baltimore, MD: Johns Hopkins UP, 1998).

Somjee, Sultan. Bead Bai (Charleston: CreateSpace Independent Publishing Platform, 2012).

www.afraso.org (last acc. 15th October, 2021) 